\title{
Survey and assessment of metals distribution in the overlying water of the representative lake and rivers in Zhenjiang, China
}

\author{
Adelaide Angela Dadzie ${ }^{1} \cdot$ Lubin Yuan $^{1} \cdot$ Shuyu Xing ${ }^{1} \cdot$ Xin Liu $^{1} \cdot$ Xiaohong Zhou $^{1}$
}

Received: 23 December 2019 / Accepted: 18 March 2020 / Published online: 29 March 2020

(c) Springer Nature Switzerland AG 2020

\begin{abstract}
In the current study, overlying water samples were collected from 21 sampling sites in representative lake and rivers in Zhenjiang, China, during winter and summer. The concentrations of $\mathrm{As}, \mathrm{Cd}, \mathrm{Cr}, \mathrm{Cu}, \mathrm{Pb}$ and $\mathrm{Zn}$ were determined, and the pollution index was assessed using single-factor and Nemerow pollution indices. Results showed that (1) the average As, $\mathrm{Cd}, \mathrm{Cr}, \mathrm{Cu}, \mathrm{Pb}$ and $\mathrm{Zn}$ concentrations were 3.75, 0.50, 2.25, 3.33, 1.30 and $21.92 \mu \mathrm{g} / \mathrm{L}$ in the winter samples and 3.62, $0.40,1.91,2.72,1.23$ and $30.76 \mu \mathrm{g} / \mathrm{L}$ in the summer samples, respectively. The concentrations of these elements were within the concentration ranges of published data on rivers or lakes in China. (2) ANOVA revealed obvious spatial, not seasonal, variations in the overlying water in this research area, except for $\mathrm{Cd}$ and $\mathrm{Zn}$. (3) The single-factor and Nemerow pollution index values were below 0.7 in all sites in the winter and summer samples, indicating that the water body had not been affected by $\mathrm{As}, \mathrm{Cd}, \mathrm{Cr}, \mathrm{Cu}, \mathrm{Pb}$ and $\mathrm{Zn}$ yet; the water quality was relatively good and free from the influence of these pollutants. (4) A significant correlation was found amongst $\mathrm{As}, \mathrm{Cd}, \mathrm{Cr}, \mathrm{Cu}$ and $\mathrm{Pb}(P<0.01)$. No significant positive or negative correlations were obtained between $\mathrm{Zn}$ and other heavy metals $(P>0.05)$, except for $\mathrm{Zn}$ and $\mathrm{Cu}(P<0.05)$ in the winter samples. Principal component analysis (PCA) verified that $\mathrm{As}, \mathrm{Cd}, \mathrm{Cr}, \mathrm{Cu}$ and $\mathrm{Pb}$ had similar distribution patterns. The correlations and PCA results indicated that the possible source of $\mathrm{As}, \mathrm{Cd}, \mathrm{Cr}, \mathrm{Cu}$ and $\mathrm{Pb}$ was geochemical role, whereas complex original sources caused by human activities may have affected $\mathrm{Zn}$ concentrations in this research region.
\end{abstract}

Keywords Metal pollution · Single-factor pollution index $\cdot$ Nemerow pollution index · Seasonal variations $\cdot$ Spatial distributions

\section{Introduction}

Water is an important material in life and one of the most affected resources in the world. Anthropogenic activities, such as rapid industrialization, advanced urbanization, population increase, agricultural production and mining, have negatively affected water resources in recent decades [1-4].

Heavy metals are environmental pollutants that elicit much concern due to their persistence and toxicity on ecological systems [5-10]. Many studies have confirmed that heavy metal residues in contaminated aquatic habitats accumulate in the bodies of microorganisms, aquatic plants and animals and ultimately enter human bodies via the food chain [7-17]. The contamination of fresh water by heavy metals causes great hazard on the ecosystem and serious health risks $[3,4,18-20]$. Therefore, heavy metal pollution in freshwater systems is a serious environmental problem and widely investigated at present [18, 21-23].

Water quality has been investigated, and the risk of heavy metals has been evaluated in different isolated regions [20]. Many studies have monitored the various concentrations of these metals to ascertain the extent of metal contamination and its implications on key lakes and riverine systems.

$\triangle$ Xiaohong Zhou, xhzhou0214@163.com|'Department of Environment Engineering, School of the Environment and Safety Engineering, Jiangsu University, 301 Xuefu Road, Zhenjiang 212013, Jiangsu, People's Republic of China. 
Water quality conditions in China have been extensively examined in the past decade because of the intense exposure of these lakes to heavy metal pollution. In Egypt, Saeed and Shaker [24] reported that the concentrations of heavy metals, including $\mathrm{Fe}, \mathrm{Zn}, \mathrm{Cu}, \mathrm{Cd}, \mathrm{Mn}$ and $\mathrm{Pb}$, in the Delta Lake are above the international permissible limit. Alarming levels of heavy metals, including $\mathrm{Pb}, \mathrm{Cd}$ and $\mathrm{Zn}$, have been reported in water bodies globally $[25,26]$. Previous research suggests that the regular distribution and concentration of heavy metals change over time and in different regions. Thus, the pollution levels in overlying water differ from region to region.

Zhenjiang is an important city in the east of China and has a population of 3.19 million. In Zhenjiang, two of the most famous rivers in China, Yangtze (approximately $103.7 \mathrm{~km}$ in Zhenjiang) and the Beijing-Hangzhou artificial canal (approximately $42.74 \mathrm{~km}$ in Zhenjiang), join only in this area. Zhenjiang has abundant water resources and a complex interwoven network. Therefore, it is one of the most important water transportation cities in China. In recent decades, chemical, papermaking and electronic industries have rapidly developed and thus accelerated economic development. At present, deterioration of water ecosystems occurs daily due to the rapid economic development and population density expansion. In our previous investigation, surface sediments collected from Jinshan Lake in October 2013 exhibited light $\mathrm{Pb}, \mathrm{Zn}$ and $\mathrm{Cd}$ pollution and moderate $\mathrm{Cr}$ pollution [27], indicating heavy metal contamination in this area. However, only sediments were studied in this research, and information on the concentrations and distributions of metals in surface water in Zhenjiang, China, is lacking. Therefore, representative lake and rivers were selected from Zhenjiang, Jiangsu, China, in the current study. The objectives were to (1) identify the distribution characteristics of As and heavy metals in the overlying water of representative lake and rivers in Zhenjiang, (2) compare the water quality in this study to the surface water environment quality standard in China (GB3838-2002) and national recommended water quality criteria (USEPA 2009), (3) assess the pollution degree of As and heavy metals by using single-factor and Nemerow pollution indices and (4) analyse the source of metals via correlation and principal component analyses. The results provide basic information for understanding the current pollution level in Zhenjiang City and can help in protecting the quality of the water environment.

\section{Materials and methods}

\subsection{Research area}

Zhenjiang City is located in the southwest of Jiangsu Province and on the south bank of Yangtze River. The city has a typical north subtropical monsoon climate. The annual mean temperature is $15.6^{\circ} \mathrm{C}$, and the rainfall amount is $1088.2 \mathrm{~mm}$, most of which is mostly concentrated in summer and fall [28-30].

Jinshan Lake is the largest shallow freshwater lake in Zhenjiang City, and it accounts for more than $80 \%$ of surface water in this region. Ancient Canal with a long history of more than 700 years is the longest time-honoured artificial river in Zhenjiang City. Yunliang, Zhoujia, Siming, Tuanjie, Hongqiaogang and Yudai Rivers are the major tributaries of Ancient Canal. The water source of Jinshan is supplied by Yangtze River, and Ancient Canal is supplied by Jinshan Lake. The parameters of Jinshan Lake and Ancient Canal have been described in our previous studies [28-31].

In the current study, 21 sampling sites were selected from Jinshan Lake, mainstream of Guyun River and the six main tributaries of Guyun River. These sampling sites were located using a global positioning system. Details of the sampling sites are provided in Fig. 1.

\subsection{Samples collected}

Overlying water samples were collected in three replicates at approximately $25-30 \mathrm{~cm}$ water depth in the 21 sites by using a water collector in January 2019 (winter) and July 2019 (summer). The samples were stored in pre-cleaned polyethylene bottles and immediately transported to the laboratory. In the laboratory, $250 \mathrm{~mL}$ of the water samples was immediately filtered through $0.45 \mu \mathrm{m}$ filter paper. Nitric acid was added to each sample until the $\mathrm{pH}$ was below 2 . The water samples were placed in a cooler at $4{ }^{\circ} \mathrm{C}$ for the analysis of As and heavy metals. In addition, the temperature and $\mathrm{pH}$ of each surface water sample were directly measured in situ at each sampling point by using $\mathrm{pH}$ and temperature metres, respectively.

\subsection{Sampling analyses}

Filtered overlying water samples were analysed for the metals $\mathrm{As}, \mathrm{Cd}, \mathrm{Cr}, \mathrm{Cu}, \mathrm{Pb}$ and $\mathrm{Zn}$ via inductively coupled plasma optical emission spectrometry (ICPE-9820, Shimadzu, Japan). All of the polypropylene containers and glassware were pre-cleaned, soaked in $5 \% \mathrm{HNO}_{3}$ for more than $24 \mathrm{~h}$, thoroughly rinsed with deionized water and dried prior to sampling and analysis. All of the reagents used in the study were of analytical grade. Reagent blanks and parallel replicates for each sample were analysed to improve the accuracy of the measurements. Calibration curves were constructed using the seven levels of standard concentrations. 
Fig. 1 The map of sampling points in the representative lake and rivers in Zhenjiang, China

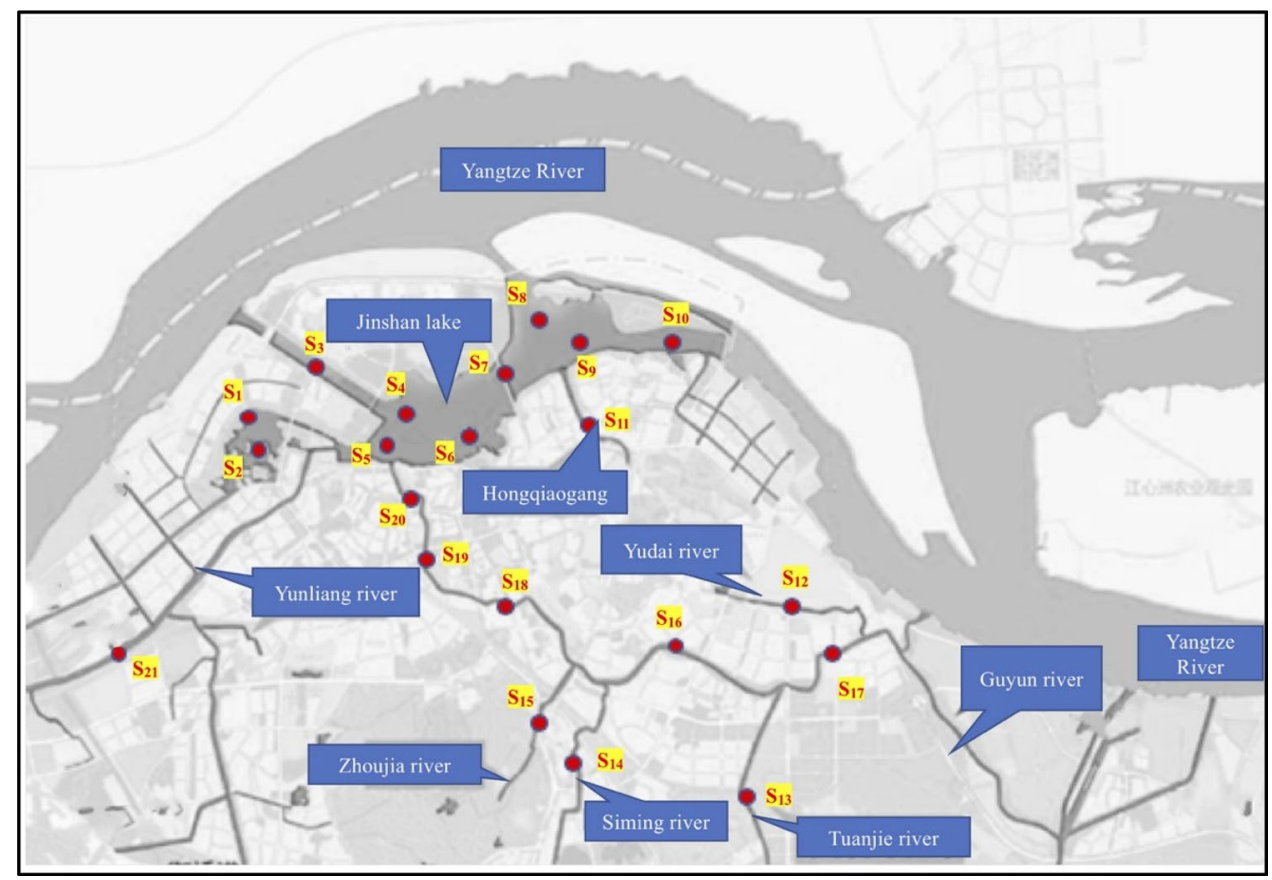

\subsection{Pollution assessment}

The single-factor pollution index $\left(P_{i}\right)$ and Nemerow pollution index $\left(P_{z}\right)$ were used to assess the pollution degree of $\mathrm{As}, \mathrm{Cd}, \mathrm{Cr}, \mathrm{Cu}, \mathrm{Pb}$ and $\mathrm{Zn}$ in the overlying waters.

The single-factor pollution index $\left(P_{j}\right)$, which is the most commonly used tool to assess water quality conditions by pollutants [32, 33], was obtained using Eq. (1) as previously reported [34, 35].

$P_{i}=\frac{C_{i}}{S_{i}}$

where $C_{i}$ (unit: $\mu \mathrm{g} / \mathrm{L}$ ) is the concentration in the overlying water and $S_{i}$ (unit: $\mu \mathrm{g} / \mathrm{L}$ ) is the concentration in the standard reference base according to the Environmental Quality Standards for Surface Water in China (GB3838-2002). The single-factor pollution index is divided into five grades, and the specific grading standards are shown in Table 1.

The Nemerow pollution index $\left(P_{z}\right)$ is frequently used to evaluate the integrated and comprehensive pollution status of heavy metals in a water body and reflects the effect of each pollutant on water quality. This parameter was calculated using Eq. (2) as previously reported [36-39].

$P_{z}=\sqrt{\frac{\left(\bar{P}_{i}\right)^{2}+\left(P_{\text {max }}\right)^{2}}{2}}$

where $\bar{P}_{i}$ is the average value of all single-factor pollution indices in the overlying water and $P_{\max }$ is the maximum value of the pollution index of all heavy metals in the overlying water. The classification criteria of the Nemerow pollution index are shown in Table 1.

\section{Results and discussion}

\subsection{Statistical results of As and heavy metals in overlying water}

The statistical results of the metals in the overlying water are presented in Table 2 . The metal concentration ranges
Table 1 Classification criteria of single-factor pollution index [34, 35] and Nemerow pollution index [36-39]

\begin{tabular}{lllll}
\hline Grade & $\begin{array}{l}\text { Single-factor pollu- } \\
\text { tion index }\left(P_{i}\right)\end{array}$ & Contamination & $\begin{array}{l}\text { Nemerow pollu- } \\
\text { tion index }\left(P_{z}\right)\end{array}$ & Contamination \\
\hline 1 & $P_{i} \leq 1$ & Non-pollution & $P_{z} \leq 0.7$ & Clean (safe) \\
2 & $1_{z}<P_{i} \leq 2$ & Slight pollution & $0.7<P_{z} \leq 1$ & Mild clean (warning line) \\
3 & $2<P_{i} \leq 3$ & Mild pollution & $1<P_{z} \leq 2$ & Slightly polluted \\
4 & $3<P_{i} \leq 5$ & Moderate pollution & $2<P_{z} \leq 3$ & Moderate polluted \\
5 & $P_{i} \geq 5$ & Heavy pollution & $P_{z}>3$ & Heavy polluted \\
\hline
\end{tabular}


in winter and summer were $3.23-5.60$ and $2.36-5.94 \mu \mathrm{g} / \mathrm{L}$ for As, $0.45-0.75$ and $0.26-0.66 \mu \mathrm{g} / \mathrm{L}$ for $\mathrm{Cd}, 1.83-3.90$ and $1.10-3.78 \mu \mathrm{g} / \mathrm{L}$ for $\mathrm{Cr}, 2.57-7.79$ and $1.21-5.47 \mu \mathrm{g} / \mathrm{L}$ for $\mathrm{Cu}, 1.11-1.98$ and $0.75-2.23 \mu \mathrm{g} / \mathrm{L}$ for $\mathrm{Pb}$ and $3.25-59.18$ and $2.78-63.42 \mu \mathrm{g} / \mathrm{L}$ for $\mathrm{Zn}$, respectively. The mean concentrations of the metals decreased in the order $\mathrm{Zn}^{>} \mathrm{As}^{>} \mathrm{Cu}^{>} \mathrm{Cr}^{>} \mathrm{Pb}^{>} \mathrm{Cd}$ in winter and summer. This result indicates that $\mathrm{Zn}$ exhibited the highest concentration in both seasons.

We compared our results with those of previous research in other rivers or lakes in China (Table 3). The average concentration of As in representative lake and rivers in Zhenjiang was close to that in Dongting Lake [40] but was lower than the average concentration of As in Dianchi Lake ( $9 \mu \mathrm{g} / \mathrm{L}$ ) [41] (Table 3). Average $\mathrm{Cd}$ and $\mathrm{Cr}$ concentrations in representative lake and rivers in Zhenjiang were also higher than those in other freshwater lakes in China, such as Dongting [40], Taihu [9], Chao [7] and Dianchi [41]. However, the average $\mathrm{Cd}$ and $\mathrm{Cr}$ concentrations in this study were lower than those in the winter water of Meiliang Bay of Taihu Lake [26], which is a highly polluted area in Taihu Lake. The average $\mathrm{Cu}$ concentration in representative lake and rivers in Zhenjiang was close to that in Dongting [40], Taihu [9], Chaohu [7] and Dianchi [41] Lakes. The average $\mathrm{Pb}$ concentrations in representative lake and rivers in Zhenjiang were lower than those in Meiliang Bay of Taihu Lake [26]. The average $\mathrm{Zn}$ concentrations were close to those of Dongting Lake [40] and Chaohu [7], but higher than those of Taihu [9] and Dianchi [41] Lakes. These comparisons indicate that the concentrations of the six elements in overlying water in the current study were within the concentration ranges in published data on in rivers or lakes in China.

Surface water is divided into five categories of guidelines (GB3838-2002) in China. Class I is a regulation for source water and national nature reserves. Class II is a regulation for habitat protection of aquatic organisms, spawning ground of fish and shrimp and food ground of juvenile fish. Class III is mainly suitable for centralized domestic drinking water from a surface water source in secondary protection zones, fish and shrimp wintering grounds, migration routes, aquaculture and other fishery waters and swimming areas. Class IV is mainly suitable for general industrial and recreational water areas without human body direct contact. Class V is mainly for agricultural water and general landscape requirements. On the basis of the guidelines of the surface water environment quality standard in China (Table 2), the concentrations of the aforementioned elements, except for $Z n$, in this study were all lower than the values of Class 1 and within the permissible limits. The $\mathrm{Zn}$ concentrations in the winter samples at site 12 belonged to Class II, and those in the other sites belonged to Class I. However, the $\mathrm{Zn}$ concentrations at sites 2, 7, 9 and 21 were 55.07, 50.65, 58.79 and $63.42 \mu \mathrm{g} / \mathrm{L}$, respectively, which are all higher than $50 \mu \mathrm{g} / \mathrm{L}$ and thus belonged to Class II. The rest of the sites belonged to Class I for summer samples. Similar results were obtained in Chaohu Lake, where the $\mathrm{Zn}$ levels in several parts of the lake were classified as Class II [7].

In accordance with the methods of Yu et al. [9] and Okbah et al. [42], the quality of the overlaying water in the current study was further compared with that prescribed by the National Recommended Water Quality Criteria (USEPA 2009) (Table 2). The results confirmed that the concentrations of $\mathrm{Cr}, \mathrm{Cu}, \mathrm{Pb}$ and $\mathrm{Zn}$ in all the sampling sites were below their criterion maximum concentration-a measure of acute toxicity (CMC), and criterion continuous concentration-a measure of chronic toxicity (CCC) values. Therefore, the research area has generally safe levels of these four heavy metals. However, the highest, average and lowest $\mathrm{Cd}$ concentrations were lower than the CMC value but higher than the CCC value for each overlying sample, indicating a potential risk.

A comparison of the results from the surface water environment quality standard in China (GB3838-2002) and the national recommended water quality criteria (USEPA 2009) showed that $\mathrm{Zn}$ and $\mathrm{Cd}$ may pose potential risks to the overlying water of the representative lake and rivers in Zhenjiang, China.

\subsection{Seasonal variations of heavy metals in overlying water}

The concentration of the six elements clearly varied with season (Fig. 2). The concentration levels and patterns of distribution of the six elements in the two seasons were dissimilar. For example, the average values of $\mathrm{As}, \mathrm{Cd}, \mathrm{Cr}, \mathrm{Cu}$ and $\mathrm{Pb}$ in the overlying water were higher in winter than in summer (Table 2). The minimum concentrations of the six elements were higher in winter than in summer. However, unlike the minimum values, the maximum $\mathrm{As}$ and $\mathrm{Pb}$ concentrations were higher in summer than in winter. The ANOVA results showed no significant difference in concentration between winter and summer $(P>0.05)$, except for $\mathrm{Cd}(P<0.01$, Table 4).

Previous research has reported seasonal variations in heavy metals in overlying water. Rajeshkumar et al. [26] showed that $\mathrm{Pb}$ and $\mathrm{Cu}$ concentrations are higher in summer than in winter, which is consistent with the results of our study. Islam et al. [43] found that $\mathrm{Cr}, \mathrm{Cu}, \mathrm{As}, \mathrm{Ni}, \mathrm{Pb}$ and $\mathrm{Cd}$ concentrations in winter are higher than those in summer. Okbah et al. [42] observed significant variations in metal concentrations, except for $\mathrm{Cr}$, between seasons. The seasonal difference in concentration might be related to the difference in the physicochemical parameters, such as $\mathrm{pH}$ and temperature, of overlying water. Wong et al. [44] 


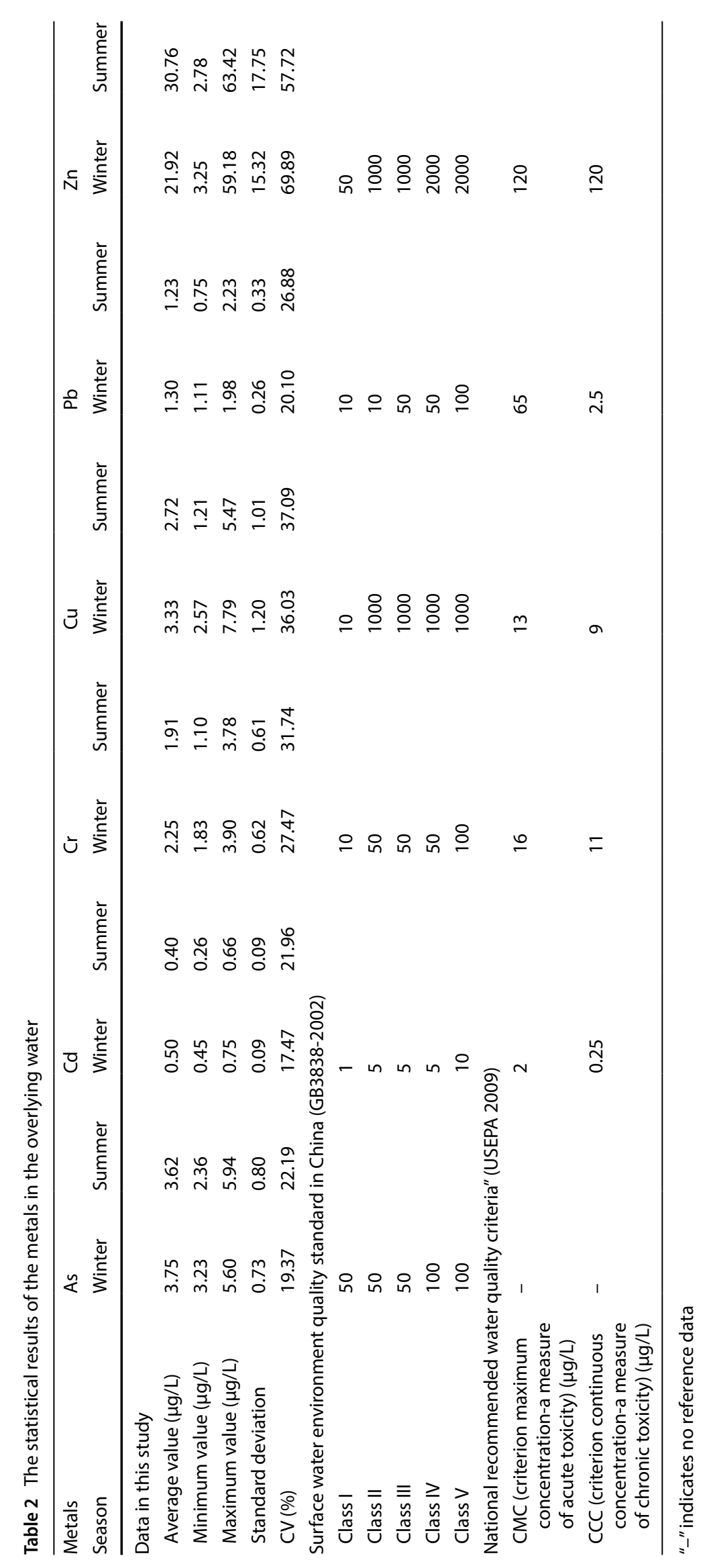


Table 3 Comparison results of metals concentration in overlying water with those of previous research in other rivers or lakes in China

\begin{tabular}{llllllll}
\hline Name of Lake & $\mathrm{As}$ & $\mathrm{Cd}$ & $\mathrm{Cr}$ & $\mathrm{Cu}$ & $\mathrm{Pb}$ & $\mathrm{Zn}$ & References \\
\hline Representative lake and rivers in Zhenjiang in winter $(\mu \mathrm{g} / \mathrm{L})$ & 3.75 & 0.50 & 2.25 & 3.33 & 1.30 & 21.92 & This study \\
Representative lake and rivers in Zhenjiang in summer $(\mu \mathrm{g} / \mathrm{L})$ & 3.62 & 0.40 & 1.91 & 2.72 & 1.23 & 30.76 & This study \\
Dongting Lake, China $(\mu \mathrm{g} / \mathrm{L})$ & 3.62 & 0.05 & 0.62 & 2.50 & 1.49 & 20.91 & Bi et al. [40] \\
Taihu Lake, China $(\mu \mathrm{g} / \mathrm{L})$ & - & 0.05 & 1.29 & 2.88 & - & 8.78 & Yu et al. [9] \\
Meiliang Bay of Taihu Lake in winter $(\mu \mathrm{g} / \mathrm{L})$ & - & 0.74 & 2.84 & 0.34 & 5.06 & - & Rajeshkumar et al. [26] \\
Meiliang Bay of Taihu Lake in summer $(\mu \mathrm{g} / \mathrm{L})$ & - & 0.24 & 0.35 & 1.96 & 6.00 & - & Rajeshkumar et al. [26] \\
Chaohu, China $(\mu \mathrm{g} / \mathrm{L})$ & 0.33 & 0.131 & 0.51 & 1.72 & 0.44 & 29.74 & Fang et al. [7] \\
Dianchi Lake, China $(\mathrm{mg} / \mathrm{L})$ & 0.009 & 0.001 & 0.004 & 0.002 & 0.266 & 0.017 & Wang et al. [41] \\
Lanzhou section of the Yellow River, China $(\mu \mathrm{g} / \mathrm{L})$ & - & 0.45 & - & 2.9 & 8.1 & 8.3 & Wang et al. [52] \\
\hline
\end{tabular}

“_" indicates no reference data
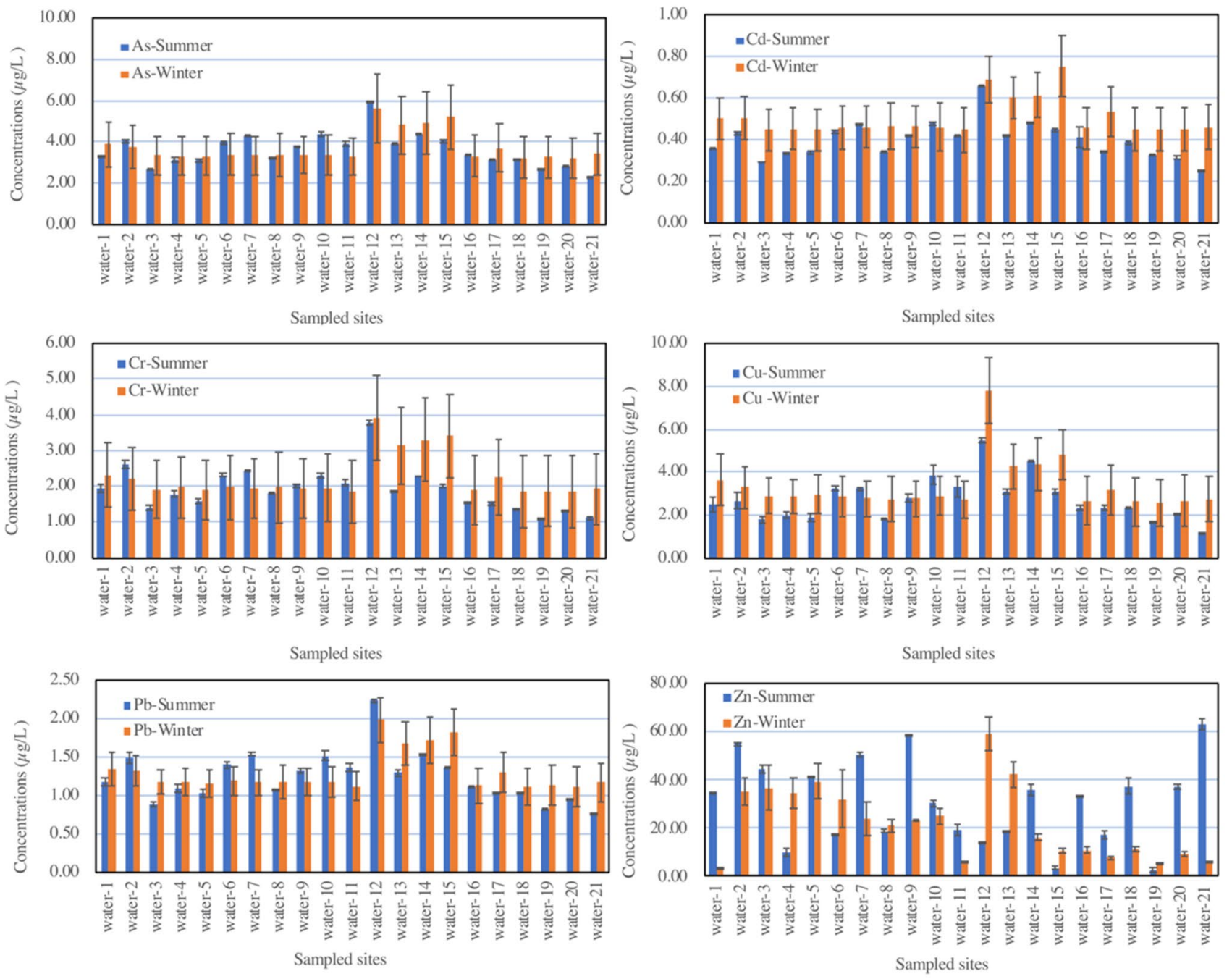

Fig. 2 Metals concentrations in overlying water collected from the representative lake and rivers in Zhenjiang, China

reported that the physical and chemical parameters of water quality potentially influence seasonal variations in heavy metal concentrations. The correlation coefficients of temperature and $\mathrm{pH}$ with metals in overlying water collected in winter in the current study are shown in Table 5. No significant correlation $(P>0.05)$ between temperature 
Table 4 ANOVA test results of metals concentration for overlying waters in the seasonal and spatial

\begin{tabular}{lll}
\hline & Spatial & Seasonal \\
\hline $\mathrm{As}$ & 0.0003 & 0.5751 \\
$\mathrm{Cd}$ & 0.2111 & 0.0004 \\
$\mathrm{Cr}$ & 0.0077 & 0.0803 \\
$\mathrm{Cu}$ & 0.0011 & 0.0807 \\
$\mathrm{~Pb}$ & 0.0006 & 0.4873 \\
$\mathrm{Zn}$ & 0.6066 & 0.0919 \\
\hline
\end{tabular}

and metal concentration was obtained in the winter and summer samples, except for $\mathrm{Cr}$ in summer samples $(P<0.05)$ (Table 5). This finding indicates that temperature was not the key factor influencing the seasonal distribution of heavy metals in this area. In addition, a strong negative significant correlation $(P<0.01)$ was found between $\mathrm{pH}$ and metal concentration in the winter samples, except for Zn (Table 5). However, in the summer samples, such a strong negative significant correlation was not obtained between $\mathrm{pH}$ and the concentration of all six metals $(P>0.05$, Table 5), indicating that the influence of $\mathrm{pH}$ on metal seasonal distribution was complicated.

The difference in the annual discharge amount of wastewater and runoff might be another factor for the seasonal difference in metal concentrations $[26,45,46]$. The lower levels of metals in summer than in winter might be due to the dilution effect of water with a larger amount of precipitation and surface runoff input in summer than in winter in the research area; hence, concentrated precipitation occurred in summer and fall. Similar results were obtained by Mohiuddin et al. [47] and Islam et al. [48].

\subsection{Spatial distributions of heavy metals in overlying water}

Spatially, the highest concentration of $\mathrm{As}, \mathrm{Cr}, \mathrm{Cu}, \mathrm{Pb}$ and $\mathrm{Zn}$ was detected in site 12 , and the peak $\mathrm{Cd}$ concentration was obtained in site 15 for water samples collected in winter (Fig. 2). The lowest values were obtained in site 20 for As, site 3 for $\mathrm{Cd}$, site 11 for $\mathrm{Cr}$, site 19 for $\mathrm{Cu}$, site 18 for $\mathrm{Pb}$ and site 1 for $\mathrm{Zn}$ for water samples collected in winter. The highest concentration of $\mathrm{As}, \mathrm{Cd}, \mathrm{Cr}, \mathrm{Cu}$ and $\mathrm{Pb}$, except for $\mathrm{Zn}$, was also detected in site 12 for water samples collected in summer. Correspondingly, the lowest values were found in site 21 for $\mathrm{As}, \mathrm{Cd}, \mathrm{Cu}$ and $\mathrm{Pb}$ and in site 19 for $\mathrm{Cr}$ and $\mathrm{Zn}$ for water samples collected in summer (Fig. 2). ANOVA showed a significant difference in concentration amongst the 21 sampling sites $(P<0.01)$, except for $\mathrm{Cd}$ and $\mathrm{Zn}(P>0.05$, Table 4$)$.

Previous studies have confirmed that significant spatial changes in element concentrations occur in lakes and rivers $[9,10,49]$. Yu et al. [9] reported that compared with lake water, river water has higher concentrations of $\mathrm{Zn}$, $\mathrm{Sb}, \mathrm{Cu}, \mathrm{Ni}$ and $\mathrm{Cr}$, which present a clear gradient from the river to Taihu Lake. The present research partly confirms this finding. In our study, we compared the average concentration of the six elements in the lake and rivers (Fig. 3). The $\mathrm{As}, \mathrm{Cd}$ and $\mathrm{Cu}$ concentrations were higher in the river than in the lake in the two seasons, but Zn concentrations were lower in the river than in the lake. Furthermore, high $\mathrm{Cr}$ and $\mathrm{Pb}$ values were observed in the river samples in winter and lake samples in summer. The element concentrations were the highest in site 12 for most of the elements because this site is located in Yudai River, which is the tributary of Guyun River and one of the most polluted rivers in the research area owing to slow water flows and large amounts of pollutants discharged.

\subsection{Pollution index evaluation of heavy metals in overlying water}

The single-factor pollution index results for each metal were calculated and are illustrated in Fig. 4. The singlefactor pollution index values in the winter samples ranged within 0.06-0.11 for As, 0.09-0.15 for Cd, 0.04-0.08 for $\mathrm{Cr}$, 0.003-0.01 for $\mathrm{Cu}, 0.02-0.04$ for $\mathrm{Pb}$ and $0.003-0.06$ for $\mathrm{Zn}$. For the summer samples, the ranges were $0.05-0.12$ for As, $0.05-0.13$ for $\mathrm{Cd}, 0.02-0.08$ for $\mathrm{Cr}, 0.001-0.01$ for $\mathrm{Cu}, 0.01-0.04$ for $\mathrm{Pb}$ and $0.003-0.06$ for $\mathrm{Zn}$. The average trend of the single-factor pollution index decreased to $\mathrm{Cd}>\mathrm{As}>\mathrm{Cr}>\mathrm{Pb}>\mathrm{Zn}>\mathrm{Cu}$ for the winter samples but was in decreasing order of $\mathrm{Cd}>\mathrm{As}>\mathrm{Cr}>\mathrm{Zn}>\mathrm{Pb}>\mathrm{Cu}$ for the summer samples.

Comparison with the grades of the single-factor pollution index showed that the values were all lower than 1 in the water samples, indicating that the overlying water was not polluted by $\mathrm{As}, \mathrm{Cd}, \mathrm{Cr}, \mathrm{Cu}, \mathrm{Pb}$ and $\mathrm{Zn}$ in winter and
Table 5 Pearson's correlation coefficients $(r)$ of temperature and $\mathrm{pH}$ with metals concentration for overlying waters

\begin{tabular}{llllllrr}
\hline Season & $\begin{array}{l}\text { Physicochemi- } \\
\text { cal parameters }\end{array}$ & & $\mathrm{Cd}$ & $\mathrm{Cr}$ & $\mathrm{Cu}$ & $\mathrm{Pb}$ & $\mathrm{Zn}$ \\
\hline \multirow{2}{*}{ Winter } & Temperature & 0.014 & 0.027 & 0.015 & 0.001 & 0.011 & -0.020 \\
& $\mathrm{pH}$ & $-0.569^{* *}$ & $-0.518^{*}$ & $-0.579^{* *}$ & $-0.589^{* *}$ & $-0.569^{* *}$ & -0.343 \\
\multirow{2}{*}{ Summer } & Temperature & 0.381 & 0.324 & $0.528^{*}$ & 0.257 & 0.429 & 0.208 \\
& $\mathrm{pH}$ & 0.069 & -0.011 & 0.216 & -0.072 & 0.109 & 0.274 \\
\hline
\end{tabular}

${ }^{*}$ and ${ }^{* *}$ significant level at $P<0.05,0.01$ level, respectively $(n=21)$ 

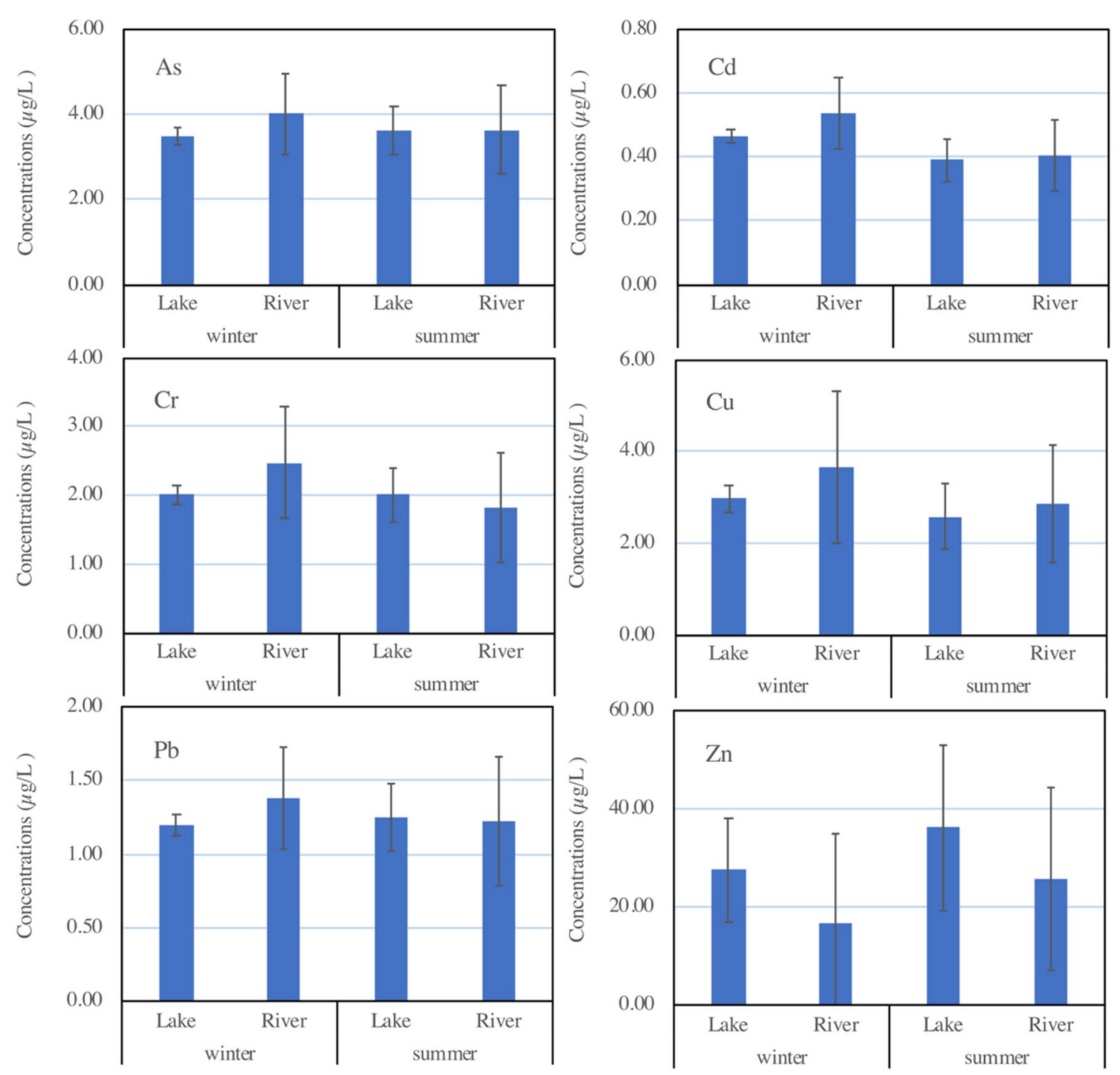

Fig. 3 Average concentrations of the metals in the representative lake and rivers in Zhenjiang, China

summer for the entire study area. The contribution of each element to the single-factor pollution index was further calculated and is shown in Fig. 5. The average contributions of $\mathrm{As}, \mathrm{Cd}, \mathrm{Cr}, \mathrm{Cu}, \mathrm{Pb}$ and $\mathrm{Zn}$ were $27.72 \%, 37.25 \%$, $16.42 \%, 1.20 \%, 9.58 \%$ and $7.82 \%$ in the winter samples and $29.18 \%, 32.18 \%, 15.18 \%, 1.07 \%, 9.86 \%$ and $12.53 \%$ in the summer samples, respectively. $\mathrm{Cd}$ had the highest contribution in the two seasons, followed by $\mathrm{As}$ and $\mathrm{Cu}$.

The results of the Nemerow pollution index were calculated and are illustrated in Fig. 6 . The values in the winter and summer samples changed from 0.097 to 0.163 and from 0.066 to 0.145 , with an average of 0.110 and 0.090 , respectively. The grades of the Nemerow pollution index were 0.7 in all of the sites. These conclusions suggest that the overlying water was not polluted by $\mathrm{As}, \mathrm{Cd}, \mathrm{Cr}, \mathrm{Cu}, \mathrm{Pb}$ and $\mathrm{Zn}$ during winter and summer in the entire study area.

\subsection{Source distribution of As and heavy metals in overlying water}

Correlations results are often used to identify the possible sources of heavy metals. Previous studies have confirmed correlations amongst heavy metals. For example, Varol and Sen [10] reported that $\mathrm{As}, \mathrm{Cu}, \mathrm{Pb}$ and $\mathrm{Zn}$ have strong correlations, and $\mathrm{Cd}, \mathrm{Co}, \mathrm{Fe}, \mathrm{Ni}, \mathrm{TP}$ and $\mathrm{TN}$ are significantly correlated; however, strong correlations were obtained between $\mathrm{Cr}$ and $\mathrm{Mn}$ in surface water from Upper 

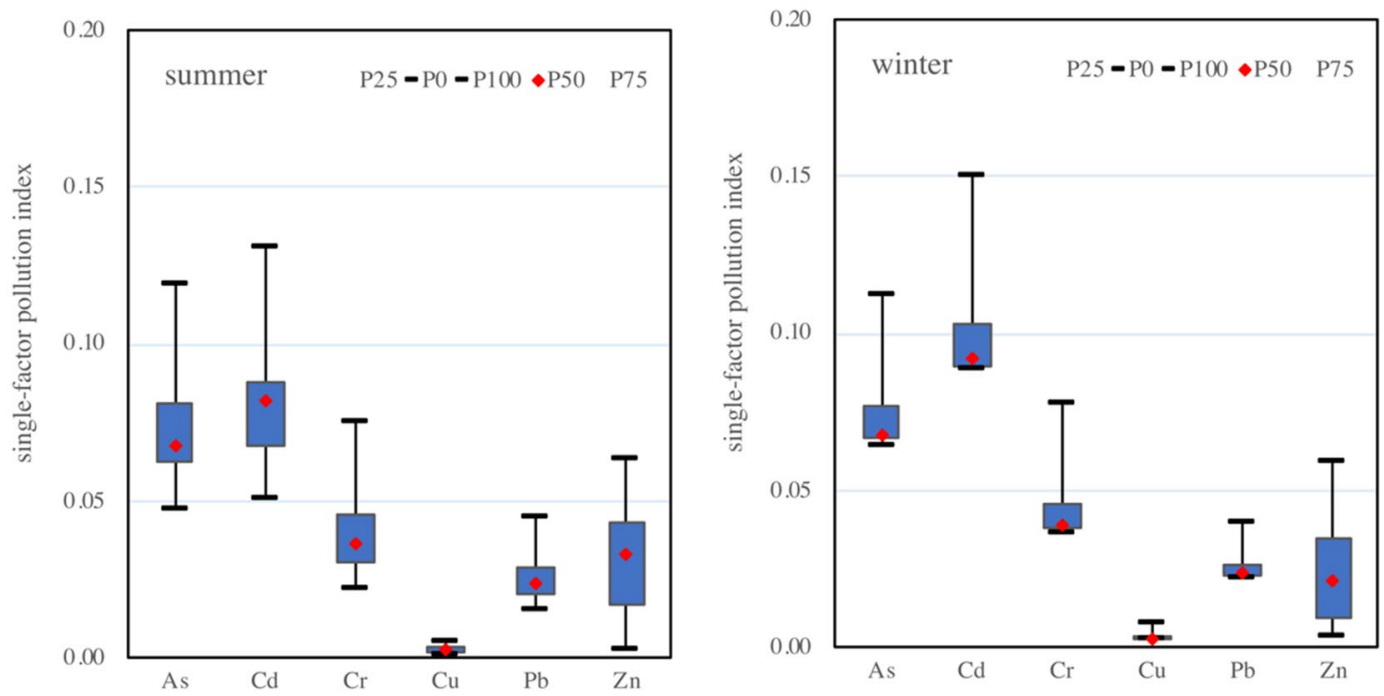

Fig. 4 Single-factor pollution index results of the metals in overlying water
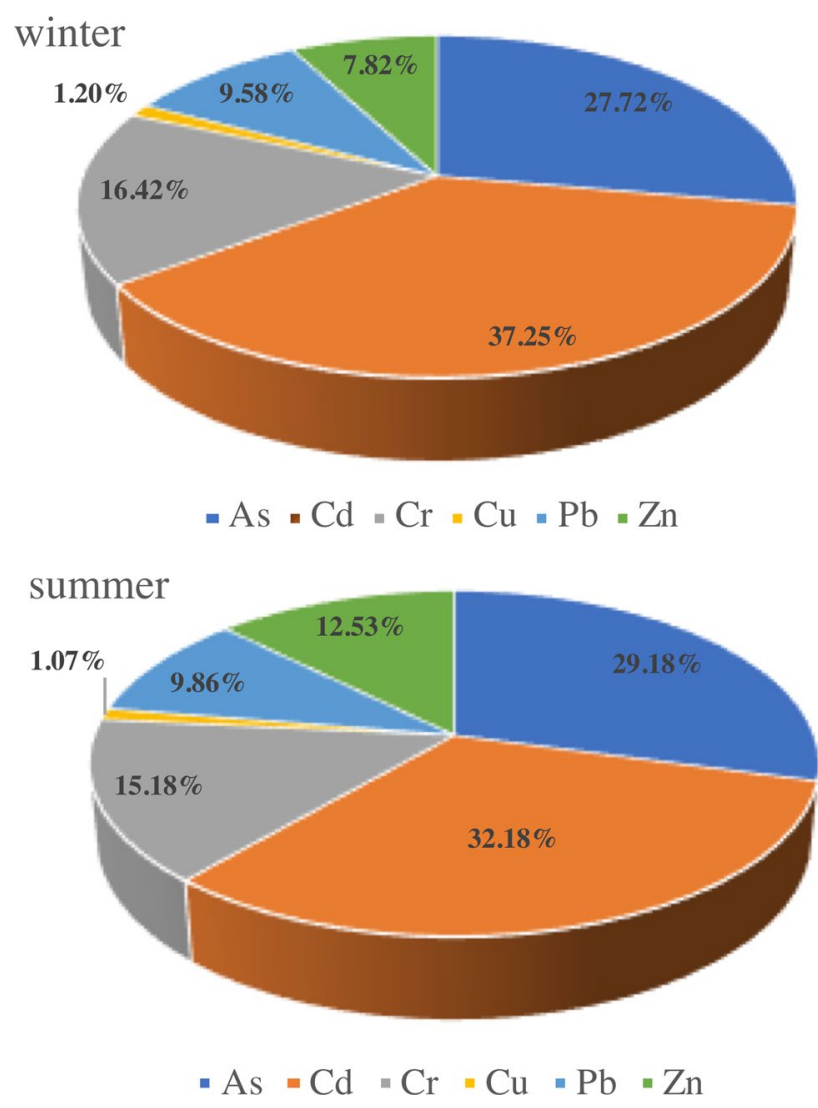

Fig. 5 Contribution of each element to the single-factor pollution index

Tigris River, Turkey. The correlation amongst the six elements for overlying waters in the current study is shown in Figs. 7 and 8. Very strong positive significant correlation was found between $\mathrm{As}$ and $\mathrm{Cd}, \mathrm{Cr}, \mathrm{Cu}$ and $\mathrm{Pb}(P<0.01)$; between $\mathrm{Cd}$ and $\mathrm{Cr}$, $\mathrm{Cu}$ and $\mathrm{Pb}(P<0.01)$; between $\mathrm{Cr}$ and $\mathrm{Cu}$ and $\mathrm{Pb}(P<0.01)$; between $\mathrm{Cu}$ and $\mathrm{Pb}(P<0.01)$; and between $\mathrm{Cu}$ and $\mathrm{Zn}(P<0.05)$ in the winter samples (Fig. 7). Significant correlation was also found amongst $\mathrm{As}, \mathrm{Cd}, \mathrm{Cr}$, $\mathrm{Cu}$ and $\mathrm{Pb}(P<0.01)$ in the summer samples (Fig. 8), indicating that the five elements may have originated from the same pollution source. However, no significant positive or negative correlations were observed between $\mathrm{Zn}$ and other heavy metals $(P>0.05)$ in this study (Fig. 8$)$, indicating that $Z n$ may have originated from sources that are different from those of other elements in this area. Similar results were reported by Liu et al. [49], who found a significant correlation amongst $\mathrm{Cd}, \mathrm{Pb}, \mathrm{Cr}, \mathrm{Cu}, \mathrm{Zn}$ and $\mathrm{As}$ in water from Jinjiang River in Chengdu, China.

The PCA results are presented in Fig. 9. For the winter samples, the first principal component (PC1) included $82.452 \%$ of all variables consisting of $\mathrm{As}, \mathrm{Cd}, \mathrm{Cr}, \mathrm{Cu}$ and $\mathrm{Pb}$. The second principal component (PC2) had positive loading on $\mathrm{Zn}$, with strong positive loading representing $15.79 \%$ of the total variance. In the summer samples, PC1 accounted for $79.807 \%$ of the total variance with high positive loading on $\mathrm{As}, \mathrm{Cd}, \mathrm{Cr}, \mathrm{Cu}$ and $\mathrm{Pb}$. $\mathrm{PC2}$ accounted for $16.921 \%$ with positive loading on $\mathrm{Zn}$. $\mathrm{PC} 1$ had positive loading on $\mathrm{As}, \mathrm{Cd}, \mathrm{Cr}, \mathrm{Cu}$ and $\mathrm{Pb}$ in the winter and summer samples. This result indicates that the five metals had similar distribution patterns. Therefore, the possible source was the geochemical role in these regions. However, for $\mathrm{Zn}$, complex original sources caused by the influence of human activities may have existed in the research area. Previous studies have found that $\mathrm{Zn}$ is often related with electroplating industries [50] and battery manufacturing [51]. In 


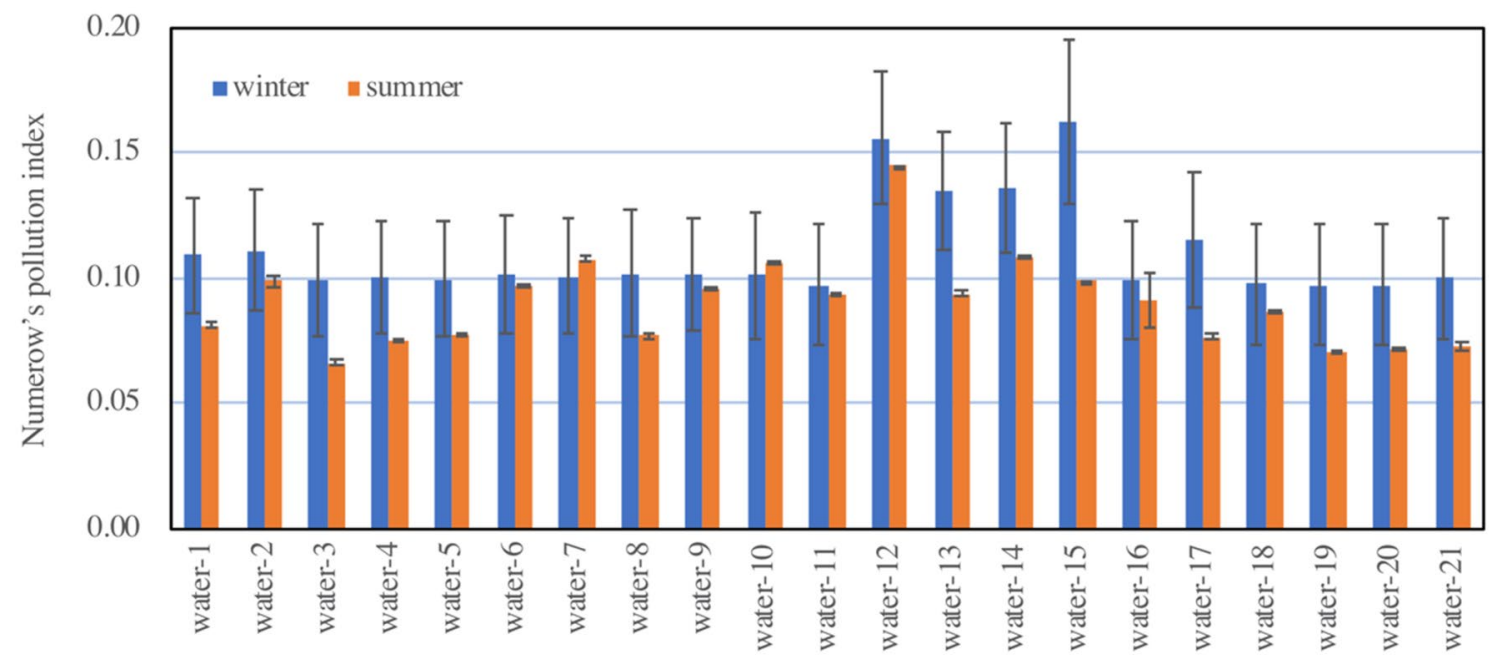

Sampled sites

Fig. 6 Nemerow pollution index results of the metals in overlying water

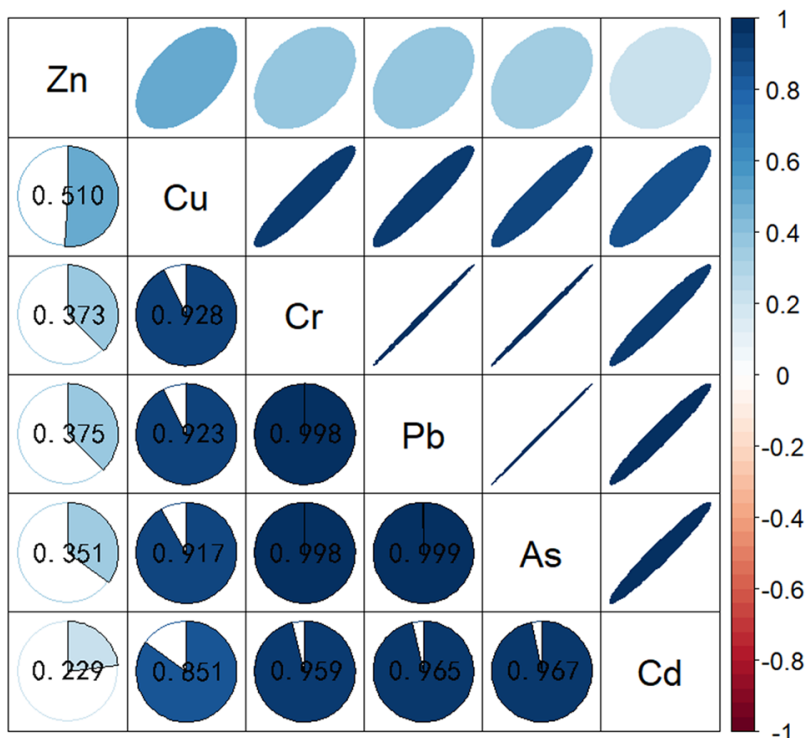

Fig. 7 The correlation amongst the six elements for overlying waters in the winter samples

our research area, drainage polluted by human activity along the shores of the lake and river may be a possible $\mathrm{Zn}$ source. Further studies should be carried out to investigate and trace the complicated source of $\mathrm{Zn}$ contamination.

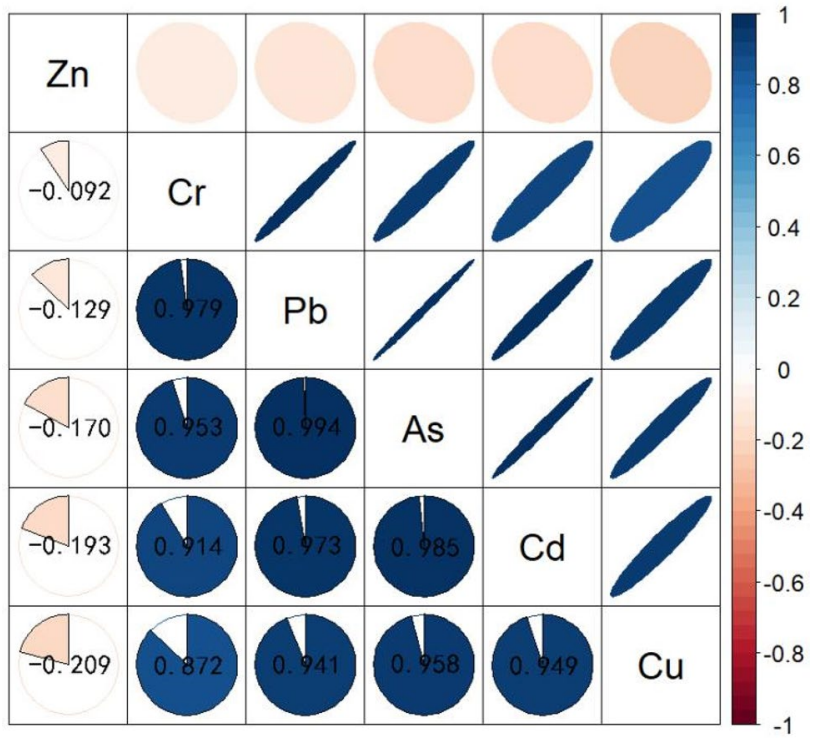

Fig. 8 The correlation amongst the six elements for overlying waters in the summer samples

\section{Conclusion}

$\mathrm{As}, \mathrm{Pb}, \mathrm{Cu}, \mathrm{Zn}, \mathrm{Cr}$ and $\mathrm{Cd}$ concentrations displayed wide spatial and seasonal variability in the overlying water from a river and a lake in Zhenjiang, China. The concentrations 

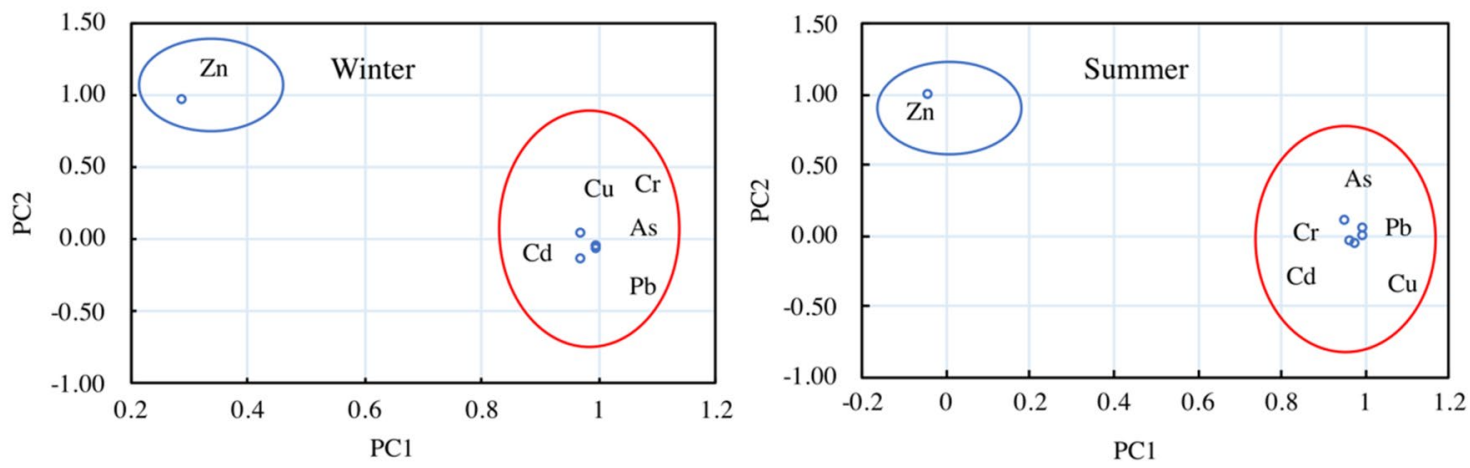

Fig. 9 Principal components analysis (PCA) results of the metals in overlying water

of these metals were all lower than the values of Class III and within the permissible limits. The evaluation results obtained from single-factor and Nemerow pollution indices showed that the overlying water was not affected by the six elements and that the water quality was relatively good and free from the influence of these pollutants. Pearson correlation and PCA results indicated that $\mathrm{As}, \mathrm{Pb}, \mathrm{Cu}$, $\mathrm{Zn}$ and $\mathrm{Cr}$ may have originated from uniform pollution sources, whereas $\mathrm{Zn}$ may have originated from a different source.

Acknowledgements This study was supported by the Jiangsu province water conservancy science and technology project (No. 2016050), by the Jiangsu provincial environmental monitoring and research fund project (No. 1816) and by the Jiangsu Collaborative Innovation Center of Technology and Material of Water Treatment.

\section{Compliance with ethical standards}

Conflict of interest The authors confirm that there is no conflict of interests.

\section{References}

1. Lu H, Li HM, Liu T, Fan YF, Yuan Y, Xie MX, Qian X (2019) Simulating heavy metal concentrations in an aquatic environment using artificial intelligence models and physicochemical indexes. Sci Total Environ 694:133591

2. Jiang Y, Ye Y, Guo X (2019) Spatiotemporal variation of soil heavy metals in farmland influenced by human activities in the Poyang Lake region, China. CATENA 176:279-288

3. Montuori P, Aurino S, Garzonio F, Nardone A, Triassi M (2016) Estimation of heavy metal loads from Tiber river to the Tyrrhenian sea and environmental quality assessment. Environ Sci Pollut Res 23:23694-23713

4. Sun XP, Bian JM, Zhang CP, Wang Y, Wan HL, Jia Z (2020) Hydrochemistry characteristics and water quality assessment for irrigation along the second Songhua river in the south of the Songnen Plain, Northeast China. Pol J Environ Stud 29(1):371-395

5. Kim JH, Lee SJ, Kim SY, Choi G, Lee JJ, Kim H-J, Kim S, Park J, Moon H-B, Choi K, Kim S, Choi SR (2016) Association of food consumption during pregnancy with mercury and lead levels in cord blood. Sci Total Environ 563-564:118-124

6. Wang Y, Wu F, Liu Y, Mu Y, Giesy JP, Meng W, Hu Q, Liu J, Dang Z (2018) Effect doses for protection of human health predicted from physicochemical properties of metals/metalloids. Environ Pollut 232:458-466

7. Fang T, Lu WX, Cui K, Li J, Yang K, Zhao XX, Liang YY, Li H (2019) Distribution, bioaccumulation and trophic transfer of trace metals in the food web of Chaohu Lake, Anhui, China. Chemosphere 218:1122-1130

8. Vu CH, Lin C, Nguyen KA, Shern CC, Kuo YM (2018) Ecological risk assessment of heavy metals sampled in sediments and water of the Houjing river, Taiwan. Environ Earth Sci 77:388

9. YuT, Zhang Y, Meng W, Hu XN (2012) Characterization of heavy metals in water and sediments in Taihu Lake, China. Environ Monit Assess 184:4367-4382

10. Varol M, Şen B (2012) Assessment of nutrient and heavy metal contamination in surface water and sediments of the upper Tigris River, Turkey. CATENA 92:1-10

11. Heshmati A, Karami-Momtaz J, Nili-Ahmadabadi A, Ghadimi S (2017) Dietary exposure to toxic and essential trace elements by consumption of wild and farmed carp (Cyprinus carpio) and Caspian kutum (Rutilus frisii kutum) in Iran. Chemosphere 173:207-215

12. Hao Y, Chen L, Zhang X, Zhang D, Zhang X, Yu Y, Fu J (2013) Trace elements in fish from Taihu Lake, China: levels, associated risks, and trophic transfer. Ecotoxicol Environ Saf 90:89-97

13. Zhang L, Campbell LM, Johnson TB (2018) Seasonal variation in mercury and food web biomagnification in Lake Ontario, Canada. Environ Pollut 161:178-184

14. Cook JA, Andrew SM, Johnson MS (1990) Lead, zinc, cadmium and fluoride insmall mammals from contaminated grass-land established on fluorspar tailings. Water Air Soil Pollut 51:43-54

15. Deniseger J, Erickson J, Austin A, Roch M, Clark MJR (1990) The effects of decreasing heavy metal concentrations on the biota of Buttle Lake. Water Res 24:403-416

16. Sin SN, Chua H, Lo W, Ng LM (2001) Assessment of heavy metal cations in sediments of Shing Mun River, Hong Kong. Environ Int 26:297-301

17. Tessier A, Campbell PGC (1987) Partitioning of trace metals in sediments: relationships with bioavailability. Hydrobiologia 149(1):43-52

18. Dash S, Borah SS, Kalamdhad A (2019) A modified indexing approach for assessment of heavy metal contamination $\mathrm{T}$ in Deepor Beel, India. Ecol Indic 106:105444

19. Tscheikner-Gratl F, Bellos V, Schellart A, Moreno-Rodenas A, Muthusamy M, Langeveld J, Clemens F, Benedetti L, 
Rico-Ramirez MA, de Carvalho RF, Breuer L, Shucksmith J, Heuvelink GBM, Tait S (2019) Recent insights on uncertainties present in integrated catchment water quality modelling. Water Res 150:368-379

20. Kumar V, Parihar RD, Sharma A, Bakshi P, Sidhu GPSA, Bali S, Karaouzas I, Bhardwaj R, Thukral AK, Gyasi-Agyei Y, RodrigoComino J (2019) Global evaluation of heavy metal content in surface water bodies: a meta-analysis using heavy metal pollution indices and multivariate statistical analyses. Chemosphere 236:124364

21. Emenike PC, Omole DO, Ngene BU, Tenebe IT (2016) Potentiality of agricultural adsorbent for the sequestering of metal ions from wastewater. Glob J Environ Sci Manag 2:411-442

22. Hanna W, Wan M, Nizam K, Maulud A, Shazwani N, Sharil S, Mundher Z (2019) Spatial and temporal risk quotient based river assessment for water re- sources management. Environ Pollut 248:133-144

23. Emenike PC, Neris JB, Tenebe IT, Nnaji CC, Jarvis P (2020) Estimation of some trace metal pollutants in River Atuwara southwestern Nigeria and spatio-temporal human health risks assessment. Chemosphere 239:24770

24. Saeed SM, Shaker IM, (2008) Assessment of heavy metals pollution in water and sediments and their effect on Oreochromis niloticus in the northern delta lakes, Egypt. In: 8th international symposium on Tilapia in aquaculture. Central Laboratory for Aquaculture Research, Agricultural Research Center, 490

25. Saleem M, Iqbal J, Shah MH (2019) Seasonal variations, risk assessment and multivariate analysis of trace metals in the freshwater reservoirs of Pakistan. Chemosphere 216:715-724

26. Rajeshkumar S, Liu Y, Zhang XY, Ravikumar B, Bai G, Li XY (2018) Studies on seasonal pollution of heavy metals in water, sediment, fish and oyster from the Meiliang Bay of Taihu Lake in China. Chemosphere 191:626-638

27. Zhou XH, Liu LM, Chen X, Chen ZG, Zhang JP, Li YM, Liu B (2014) Heavy metals distribution characteristics and ecological risk evaluation in surface sediments of dammed Jinshan lake. Environ Sci 35(11):4127-4134 (in Chinese)

28. Zhou XH, Wang MY, Liu LM, Chen ZG, Li YM, Zhang JP (2015) Nitrogen dynamics variation in overlying water of Jinshan Lake, China. J Chem 55:759496

29. Zhou XH, Li YM, Wen CZ, Liu D (2019) Distribution characteristics of anammox bacteria in ancient canal (Guyun river) riparian sediment of Zhenjiang, China. Geomicrobiol J 36(3):243-250

30. Zhou XH, Li YM, Zhang JP, Liu B, Wang MY, Zhou YW, Lin ZJ, He ZL (2016) Diversity, abundance and community structure of ammonia-oxidizing archaea and bacteria in riparian sediment of Zhenjiang ancient canal. Ecol Eng 90:447-458

31. Liu B, Li YM, Zhang JP, Zhou XH, Wu CD (2014) Abundance and diversity of ammonia-oxidizing microorganisms in the sediments of Jinshan lake. Curr Microbiol 69:751-757

32. Yan CA, Zhang WC, Zhang Z, Liu Y, Deng C, Nie N (2015) Assessment of water quality and identification of polluted risky regions based on field observation \& GIS in the Honghe River Watershed, China. PLoS One 10(3):1-13

33. Zhu SL, Mostafaei A, Luo WG, Jia BY, Dai JY (2019) Assessing water quality for urban tributaries of the Three Gorges Reservoir, China. J Water Reuse Desalin 9:105-113

34. Jaffar STA, Luo F, Ye R, Younas H, Hu XF, Chen LZ (2017) The extent of heavy metal pollution and their potential health risk in topsoils of the massively urbanized district of Shanghai. Arch Environ Contam Toxicol 73:362-376

35. Zhang SW, Wang LJ, Zhang WJ, Wang L, Shi XM, Lu XW, Li XP (2019) Pollution assessment and source apportionment of trace metals in urban topsoil of Xi'an city in northwest China. Arch Environ Contam Toxicol 77(4):575-586
36. Liu S, Zhang Y, Bi S, Zhang X, Li X, Lin M, Hu G (2015) Heavy metals distribution and environmental quality assessment for sediments off the southern coast of the Shandong Peninsula, China. Mar Pollut Bull 100:483-488

37. Mazurek R, Kowalska J, Gasiorek M, Zadrozny P, Jozefowska A, Zaleski T, Kepka W, Tymczuk M, Orłowska K (2016) Assessment of heavy metals contamination in surface layers of Roztocze National Park forest soils (SE Poland) by indices of pollution. Chemosphere 168:839-850

38. Zhang Y, Chu C, Li T, Xu S, Liu L, Ju M (2017) A water quality management strategy for regionally protected water through health risk assessment and spatial distribution of heavy metal pollution in 3 marine reserves. Sci Total Environ 599-600:721-731

39. Shil S, Singh UK (2019) Health risk assessment and spatial variations of dissolved heavy metals and metalloids in a tropical river basin system. Ecol Ind 106:105455

40. Bi B, Liu XH, Guo XC, Lu SY (2018) Occurrence and risk assessment of heavy metals in water, sediment, and fish from Dongting Lake, China. Environ Sci Pollut Res 25:34076-34090

41. Wang ZX, Yao L, Liu GH, Liu WZ (2014) Heavy metals in water, sediments and submerged macrophytes in ponds around the Dianchi Lake, China. Ecotoxicol Environ Saf 107:200-206

42. Okbah MA, Abdelhalim AM, Abu El-Regal MA, Soliman NF, Nassar MEM (2018) Metals in a northern Nile Delta lake: water, suspended particulates, sediments, and biota. Environ Sci Pollut Res 25:33967-33977

43. Islam MS, Ahmed MK, Raknuzzaman M, Habibullah-Al-Mamun M, Islam MK (2015) Heavy metal pollution in surface water and sediment: a preliminary assessment of an urban river in a developing country. Ecol Ind 48:282-291

44. Wong CK, Wong PPK, Chu LM (2001) Heavy metal concentrations in marine fishes collected from fish culture sites in Hong Kong. J Arch Environ Contam Toxicol 40:60-69

45. Tekin-Ozan S, Kir I (2008) Seasonal variations of heavy metals in some organs of carp (Cyprinus carpio L., 1758) from Beyşehir Lake (Turkey). Environ Monit Assess 138:201-206

46. Duman F, Kar M (2012) Temporal variation of metals in water, sediment and tis-sues of the European Chup (Squalius cephalus L.). Bull Environ Contam Toxicol 89:428-433

47. Mohiuddin KM, Otomo K, Ogawa Y, Shikazono N (2012) Seasonal and spatial distribution of trace elements in the water and sediments of the Tsurumi River in Japan. Environ Monit Assess 184:265-279

48. Islam MS, Han S, Masunaga S (2014) Assessment of trace metal contamination in water and sediment of some rivers in Bangladesh. J Water Environ Technol 12:109-121

49. Liu XP, Jiang JY, Yan Y, Dai YY, Deng B, Ding SL, Su SJ, Sun WY, Li Z, Gan ZW (2018) Distribution and risk assessment of metals in water, sediments, and wild fish from Jinjiang River in Chengdu, China. Chemosphere 196:45-52

50. Fu J et al (2014) Heavy metals in surface sediments of the Jialu river, China: their relations to environmental factors. J Hazard Mater 270:102-109

51. Zhao DJ, Ma SY, Tian XQ, Bai XB (2006) Status of recovery and utilization of waste and used $\mathrm{Zn}-\mathrm{Mn}$ battery. China Resour Compr Util 3:006 (in Chinese)

52. Wang YM, Chen P, Cui RN, Si WT, Zhang YM, Ji WH (2010) Heavy metal concentrations in water, sediment, and tissues of two fish species (Triplohysa pappenheimi, Gobio hwanghensis) from the Lanzhou section of the Yellow River, China. Environ Monit Assess 165:97-102

Publisher's Note Springer Nature remains neutral with regard to jurisdictional claims in published maps and institutional affiliations. 